\title{
Redesign of Artificial Lighting with Electricity Saving Aspects
}

\author{
Linwan Abadi Harefa \\ Department of Electrical Engineering \\ Universitas Riau \\ Indonesia
}

\author{
Feranita* \\ Department of Electrical Engineering \\ Universitas Riau \\ Indonesia
}

\author{
Edy Ervianto \\ Department of Electrical Engineering \\ Universitas Riau \\ Indonesia
}

*corresponding author: Feranita, feranita@lecturer.unri.ac.id

\begin{abstract}
Redesign of artificial lighting with electricity saving aspects at the Putri Tujuh Ujung Batu Foundation aims to evaluate the design of artificial lighting systems in several rooms including the Inayah Islamic Elementary School Office, Putri Tujuh Orphanage Dormitory and Fastabiqul Khairat Mosque by calculating aspects of energy savings. Initial measurement results show that the lighting strength in each room does not meet the specified standards. The measurement results are measured using the zonal cavity method. It is recommended that the type of lamps used are 2 Philips LED 27 Watt lamps and 33 Philips LED 33 Watt lamps. Calculations with this method are simulated using the DiaLux Evo V.8.2 software which displays a three-dimensional image along with the strength of the lighting in each room. From the simulation results, it was determined that the use of pure white paint coated walls increases the lighting strength. The percentage of electricity savings for Inayah Islamic Elementary School office space was $31.25 \%$. Putri Tujuh Orphanage dormitory was $61.64 \%$ and the Fastabiqul Khairat mosque was $7.11 \%$ when compared to the use of Hannochs lamps.
\end{abstract}

Keywords- zonal cavity method, EvoDialux software, electricity saving.

\section{INTRODUCTION}

Lighting plays an important part in meeting the lighting needs in a building that supports the function of the room in carrying out various indoor activities so as to bring comfort to the room user. Planning the lighting installation in a building should give attention to lighting design and distribution of light in the room because this will greatly affect the activities of its users. In designing the lighting system, an engineer will refer to the lighting standard recommendations illumination.

Office rooms, mosques and multipurpose halls are places of work and worship activities. The place must be comfortable, both visually and efficiently in energy utilization. Lighting in the room must meet the needs of comfort and health. Comfort in lighting can be achieved if visual comfort can be realized properly, including the suitability of the design and layout of the room in accordance with the distribution of lighting.
Lighting needs in a room can be obtained through artificial lighting systems and natural lighting systems such as sunlight. The general principle of lighting is that excessive light does not have a better effect. Vision does not get better only from the amount or quantity of light but also from its quality. The quantity and quality of good lighting is determined by the level of light reflection and the level of lighting ratio in the room (Irianto, 2006).

Lighting from the meaning of quality is the power of illumination or the level of illumination needed for different types of activities will require different levels of illumination (Atmam, 2016).

There are several factors in a room lighting system that must be considered, such as the need for electricity used, maintenance costs and energy consumption expenses. Therefore the lighting system must also consider the terms of saving electrical energy.

In this study, an evaluation and redesign of artificial lighting with the aspects of electricity energy saving was conducted at Putri Tujuh Ujung Batu Foundation. According to the Indonesian National Standard SNI 6197-2011 the minimum expected lighting strength for office space is 350 Lux, for lighting in a mosque is 200 Lux, living room lighting is 150 Lux and the multipurpose hall is 200 Lux. Based on this, it is very necessary to do research on the redesign of lighting in these rooms with the aspect of saving the use of electrical energy so that the cost of energy used becomes less.

\section{BASIC THEORY}

\section{A. Lighting}

Light is a type of electromagnetic waves that radiates in the air where the waves have a certain length and frequency whose number or value can be distinguished from other light energy in the electromagnetic spectrum (Suhardi, 2008).

According to the Great Indonesian dictionary, the definition of light is a ray of light or light from an object that shines like the sun that can cause the eye to catch shadows from surrounding objects that are exposed to light. 
Lighting is the value of light in a field that is needed to perform activities properly. Lighting has a unit known as Lux $(\mathrm{lm} / \mathrm{m} 2)$, where $\operatorname{lm}$ is Lumen and $\mathrm{m}^{2}$ is the Unit of Surface Area.

\section{B. Lighting Criteria}

According to the research of Wibiyanti (2008), the main functions of artificial lighting in the work environment, which are applied separately or combined with natural lighting are:

a) It presents an environment where the eye can see well so that visual activities are carried out easily and precisely.

b) It enables humans to walk and move easily and safely.

c) It does not cause an excessive increase in air temperature in the irradiated place.

d) It provides strong illumination that spreads evenly in every corner of the room, without blinking, excessive or can be blinding and does not cause distracting shadows.

Improve the comfortable visual environment.

\section{Lighting Source}

In general, lighting sources can be divided into two, namely natural lighting and artificial lighting. Natural Lighting is a light produced by natural light sources such as the sun with strong lighting varies according to time, season and place. Artificial Lighting is all forms of light sources created by humans, such as incandescent lamps and candles (Satwiko, 2008). The main source of artificial lighting today comes from electrical energy. The amount of light and color of the light varies depending on the type of electric light source used.

\section{Artificial Light Sources}

1. Incandescent Light Groups

The working principle of incandescent lamps is the existence of an electric current flowing through a filament that has high resistivity and causes voltage losses. This, in turn, causes power loss so that it produces heat in the filament. Filaments are incandescent and produce light (Ikhbal, 2017).

\section{The Rotating Lamp Type}

Fluorescent lamps (TL) are commonly referred to as Neon lights. Light on Neon Lights is usually white. White light (cool light) on neon lights provide a cool effect. The light emitted by fluorescent lamps is brighter than incandescent and halogen lamps because these lamps have higher efficacy than incandescent lamps.

\section{Light Emitting Diode (LED) Lamp}

LED light (Light Emitting Diode) has a very long after use, reaching 100,000 hours with very little electricity consumption. The variations in color on the LED lights make it possible to create an atmosphere of space and objects that are always changing by playing different colors at a certain time.

\section{E. Zonal Cavity Method}

The Zonal Cavity method or called the room volume method is one of the methods commonly used to calculate the average illumination level of a lighting system in a room based on the concept of volume distribution in a room. This method can easily determine the average light level and the number of lights installed.

a. Room Cavity Ratio (RCR)

$$
R C R=\frac{P \times L}{\operatorname{hrc} x(P+L)}
$$

\section{b. Determine the Coefficient of Utilization (CU) Value}

The value of the room volume and the percentage of reflections from the ceiling, walls, and floor are used to determine the value of the Utilization Coefficient. Usually, the $\mathrm{CU}$ value can be seen in the table issued by the manufacturer and the IES (Illumination Engineering Society) handbook.

\section{c. Determine the Value of Light Loss Factor (LLF)}

All equipment, in general, has losses including lamps. The value of LLF is between $0.7-0.8$. In this study using 0.8 by assuming that the cleanliness of the room is maintained properly.

\section{d. Count the Number of Luminaries}

To get the number of lamps needed, the following formula is used:

$$
N=\frac{E \times A}{n \times \phi \times C U \times L L F}
$$

The following is the average exposure level recommended by the Indonesian National standard number 6197 the year 2011.

Table 1: levels of SNI recommendation lighting

\begin{tabular}{|l|l|}
\hline Room Function & Lighting Level (lux) \\
\hline Workspace & 350 \\
\hline Mosque & 200 \\
\hline Multipurpose Hall & 200 \\
\hline Living room & 150 \\
\hline Workspace & 350 \\
\hline
\end{tabular}

\section{F. Dialux Software}

DIALux is a software used for natural and artificial lighting simulation purposes. DIALux can be simulated for indoor or outdoor lighting. Its function is to build lighting in a 3dimensional display and can also estimate the light and provide lighting level calculations based on the parameters entered. Dialux uses a calculation method based on the zonal cavity lighting system formula

\section{ReSEARCH METhodology}

This study uses a direct observation method to the location of research observations including school buildings, namely Inayah Ujung Batu Vocational Middle School, 
Inayah Ujung Batu Islamic Middle School, Inayah Ujung Batu Islamic Elementary School, Putri Tujuh Ujung Batu Orphanage, Fastabiqul Khairat Mosque. Measurements were carried out for several days to obtain room data and measurement data of existing lighting at the research location. Before measuring the strength of the lighting, the length, width, and height of the room are measured. This is needed to determine the measurement points of lighting strength. Furthermore, the level of lighting is checked by direct measurement. If the results of direct measurements are obtained below the minimum standard recommended by SNI No. 6197 In 2011, it is necessary to recalculate the lighting system by updating the type of lamp that will be used to improve the quality of lighting.

Mathematical calculations are performed using the lumen method to get the number of luminaires needed in the room so that it reaches the minimum standard specified. Previously obtained data is entered into the room cavity ratio equation, determining the value of the reflection zone (ceiling, wall and work area), the Coefficient of Utilization (CU) value and the Light Loss Factor (LLF) value. The next process is to enter the calculated equation value and the specified value into the final equation to get the number of luminaires needed.

After going through a mathematical calculation process using the lumen method, the next step is to simulate the room using the DiaLux Evo software. If the simulation results in the software do not reach the minimum standards specified, then it is necessary to re-examine the mathematical calculations and designs made. After the direct measurement process, recalculation and room simulation in the software are obtained, the next step is to analyze the results obtained from the procedures that have been carried out. In improving the quality of lighting systems, investment value must be included.

\section{Results AND Discussion}

This section explains the effects of direct measurements of lighting levels, recalculating the number of luminaires needed by using existing lamps and suggested lamps as well as room simulations and finally calculating the energy and cost comparisons needed to improve previous conditions. The types of lights used in this study are Philips 27 Watt 3000 Lumen LED lamps and Philips 33 Watt 4000 Lumen LEDs.

Table 2: Direct Measurement of Lighting Strength value

\begin{tabular}{|l|l|l|l|}
\hline \multicolumn{1}{|c|}{ Room } & $\begin{array}{l}\text { Room } \\
\text { Function }\end{array}$ & Lamp type & $\begin{array}{l}\text { Average lighting } \\
\text { strength }\end{array}$ \\
\hline $\begin{array}{l}\text { Room of SD } \\
\text { Islam Inayah } \\
\text { Principal }\end{array}$ & Workspace & $\begin{array}{l}2 \text { pieces of } \\
\text { Hannochs } 8 \\
\text { Watt }\end{array}$ & 81,8 Lux \\
\hline $\begin{array}{l}\text { The living room } \\
\text { of the PutriTujuh } \\
\text { orphanage }\end{array}$ & Living room & $\begin{array}{l}1 \text { piece of } \\
\text { Hannochs 26 } \\
\text { Watt }\end{array}$ & 79 Lux \\
\hline $\begin{array}{l}\text { Hall of the } \\
\text { PutriTujuh } \\
\text { dormitory }\end{array}$ & $\begin{array}{l}\text { Multipurpose } \\
\text { Hall pieces of } \\
\text { Hannochs 45 } \\
\text { Watt }\end{array}$ & $\begin{array}{l}2 \text { pieces of } \\
\text { Hannochs 45 } \\
\text { Watt, 6 pieces } \\
\text { of Hannochs } \\
23 \text { Watt }\end{array}$ & \multicolumn{1}{|c}{ lux } \\
\hline $\begin{array}{l}\text { Fastabiqul } \\
\text { Khairat Mosque }\end{array}$ & Mosque & & \\
\hline
\end{tabular}

\section{A. Mathematical Calculations Using Lumen Methods}

Room of SD Islam Inayah Principal

- Using Hannochs lamp 8 Watt 440 Lumen

$$
\begin{aligned}
& N=\frac{E \times A}{n \times \phi \times C U \times L L F} \\
& N=\frac{350 \times 19,2}{1 \times 440 \times 0,6255 \times 0,8}=30,5 \approx 30
\end{aligned}
$$

- Using Philips LED Lights 33 Watt 4000 Lumen

$$
\begin{aligned}
& N=\frac{E \times A}{n \times \phi \times C U \times L L F} \\
& N=\frac{350 \times 19,2}{1 \times 4000 \times 0,4035 \times 0,8}=5,2 \approx 5
\end{aligned}
$$

The living room of Orphanage Putri Tujuh Dorm

- Using Hannochs lamp 26 Watt 1560 Lumen. Based on equation 2 , the number of lamps required is:

$$
N=\frac{150 \times 19,25}{1 \times 1560 \times 0,585 \times 0,8}=3,9 \approx 4
$$

- Using a Philips LED lamp 27 Watt 3000 Lumen.

Based on equation 2, the number of lamps required is:

$$
N=\frac{150 \times 19,25}{1 \times 3000 \times 0,54 \times 0,8}=2,2 \approx 2
$$

Multipurpose Putri Tujuh orphanage Hall Room

- Using Hannochs lamp 45 Watt 2700 lumens

Based on equation 2, the number of lights needed is:

$$
N=\frac{200 \times 92}{1 \times 2700 \times 0,571 \times 0,8}=14,9 \approx 15
$$

- Using Philips LED Light 33 Watt 4000 Lumen.

Based on equation 2, the number of lamps required is:

$$
N=\frac{200 \times 92}{1 \times 4000 \times 0,6244 \times 0,8}=9,2 \approx 9
$$

The room inside the Fastabiqul Khairat Mosque

- Using Hannochs lamp 45 Watt 2700 lumens.

Based on equation 2, the number of lamps required is:

$$
N=\frac{200 \times 213,16}{1 \times 2700 \times 0,531 \times 0,8}=37,2 \approx 37
$$

- Using Philips LED Lights 33 Watt 4000 Lumen

Based on comparison 2, the number of lights needed is:

$$
N=\frac{200 \times 213,16}{1 \times 4000 \times 0,69 \times 0,8}=19,3 \approx 19
$$

\section{B. Simulated Results Using DialuxEvo 8.2}

Room of SD Islam Inayah Principal

Inayah Islamic Elementary School Principal's Room 
After performing manual calculations with the zonal cavity method, the calculation results are then simulated with the DiaLux Evo V.8.2 Software. The simulation results are in Figure 1, it can be seen that in the room the lights are already on. This is done to determine lighting stength in the room.

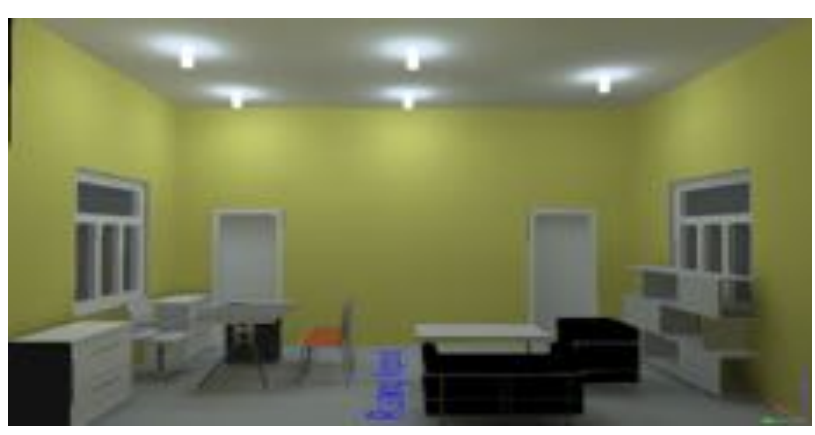

Figure 1. School Principal Simulation Results

Figure 2 shows the average magnitude of lighting obtained from 5 lamps, which is 376 lux and meets the minimum recommendation in a work room or office that is 350 lux.

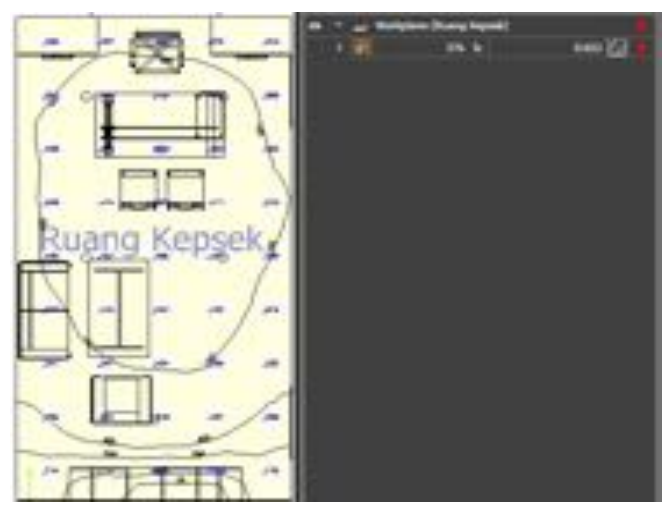

Figure 2. The average magnitude of lux produced in the Principal's Room

1) Guest Room of Putri Tujuh Orphanage's Dormitory

The simulation results are in Figure 3 where in the room the lights are already on. This is done to find out the lighting strength in the room.

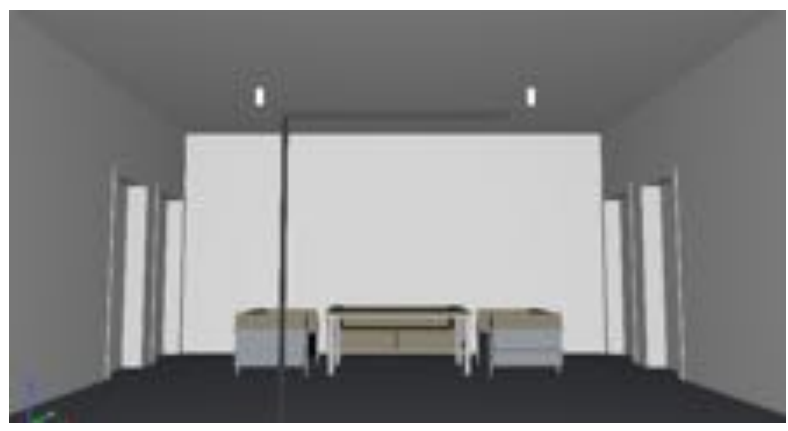

Figure 3 Simulation Results of the Guest Room
In Figure 4, the average magnitude of lighting obtained from 2 lamps is 165 lux and meets the minimum recommendation size in the guest room, which is 150 lux.

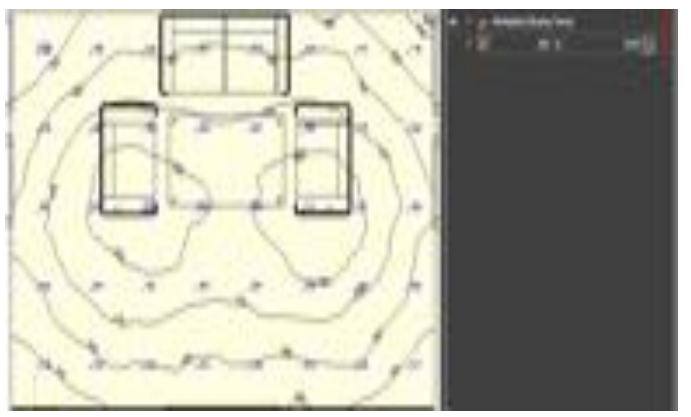

Figure 4. The average magnitude of lux produced

2) Multipurpose Hall Room for Putri Tujuh Orphanage Dormitory

The simulation results are in Figure 5 where in the room the lights are already on. This is done to find out the lighting strength in the room

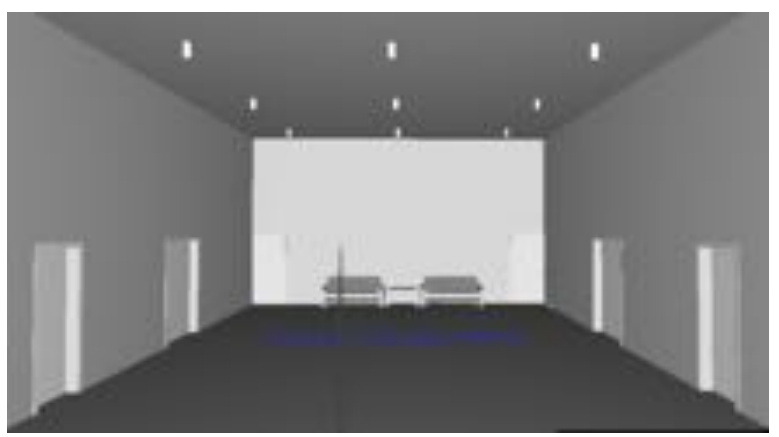

Figure 5 Hall Room Simulation Results

In Figure 6, the average magnitude of lighting obtained from 9 lamps is 204 lux and meets the minimum recommendation in the Hall of 200 lux.

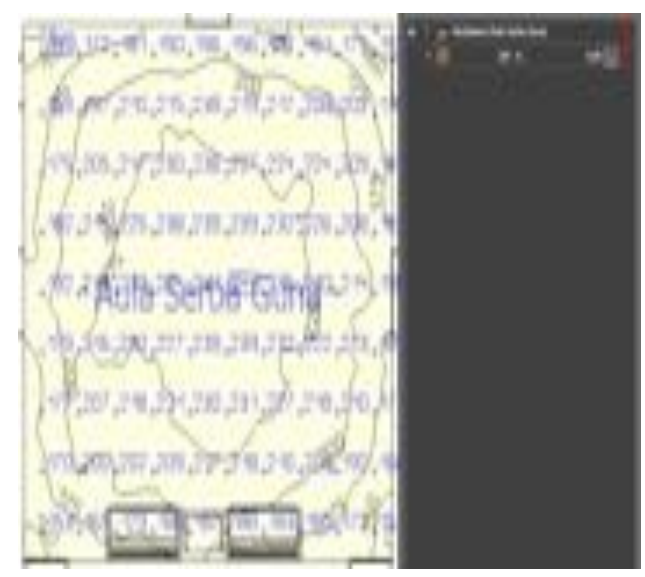

Figure 6. The average magnitude of lux produced 
3) The Fastabiqul Khairat Mosque Room

The simulation results are in Figure 7 where in the room the lights are already on. This is done to find out the lighting strength in the room.

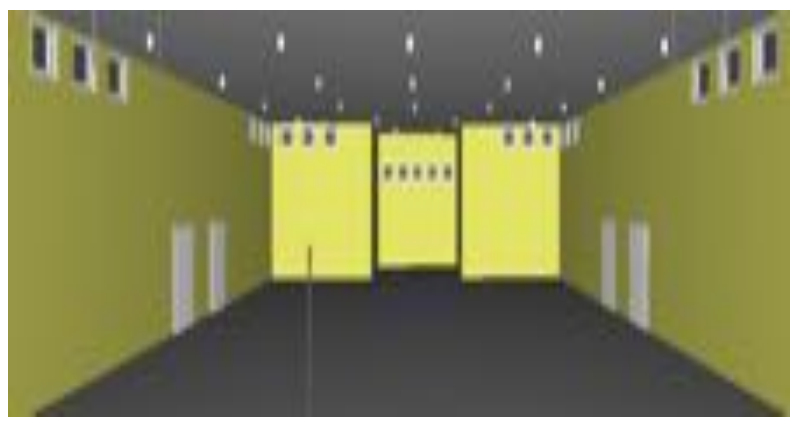

Figure 7 Mosque Room Simulation Results

In Figure 8, the average magnitude of lighting obtained from 19 lamps is 214 lux and meets the minimum recommendation in the Worship room at 200 lux.

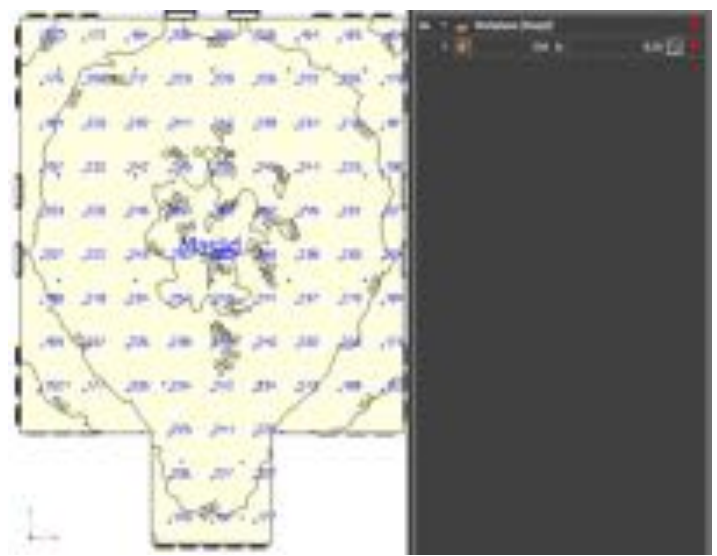

Figure 8 the average magnitude of lux produced

Table 3. Results Analysis and simulations of the number of lights

\begin{tabular}{|l|l|l|l|}
\hline \multicolumn{1}{|c|}{ Room } & $\begin{array}{l}\text { Room } \\
\text { Function }\end{array}$ & $\begin{array}{l}\text { Average } \\
\text { lighting } \\
\text { strength }\end{array}$ \\
\hline $\begin{array}{l}\text { Room of SD } \\
\text { Islam Inayah } \\
\text { Principal }\end{array}$ & Workspace & $\begin{array}{l}5 \text { pieces Philips } \\
\text { LED 33 Watt }\end{array}$ & 376 Lux \\
\hline $\begin{array}{l}\text { Living room } \\
\text { of the Putri } \\
\text { Tujuh } \\
\text { orphanage }\end{array}$ & Living room & $\begin{array}{l}2 \text { pieces Philips } 27 \text { Watt } \\
\text { LED }\end{array}$ & 165 Lux \\
\hline $\begin{array}{l}\text { Hall of the } \\
\text { Putri Tujuh } \\
\text { dormitory } \\
\text { room }\end{array}$ & $\begin{array}{l}\text { Multipurpose } \\
9 \text { pieces Philips } \\
\text { LED 33 Watt }\end{array}$ & 204 Lux \\
\hline $\begin{array}{l}\text { Fastabiqul } \\
\text { Khairat } \\
\text { Mosque }\end{array}$ & Mosque & $\begin{array}{l}19 \text { pieces Philips } \\
\text { LED 33 Watt }\end{array}$ & 214 Lux \\
\hline
\end{tabular}

\section{Effect of Wall Color Coating on Lighting Strength}

Basically the color coating on the wall affects the lighting strength in the room. This can increase or reduce the lighting strengt. In this study, the authors recommend using a Pure White colored wall coating with a reflectance factor of $86 \%$. Simulation results show that the coating of different materials affects the strength of the lighting. In the Inayah Islamic Primary School Principal's Room, the lighting increased from 376 Lux to 547 Lux. Putri Tujuh Orphanage Dormitory Guest Room 165 Lux becomes 198 Lux. The Multipurpose Hall Room of the Putri Tujuh Orphanage Dormitory 204 Lux became 277 Lux and the Fastabiqul Kharait Mosque room increased the lighting from 214 Lux to 275 Lux.

\section{Economical Study}

Different types of lamps affect the level of expenditure on investment costs in an overall lighting system. In this case the authors take the unit price of 33 watt Philips LED lamps in the Bukalapak online store.

- Total LED Lamp Philips 33 Watt

- 33 x Rp. $175,000=$ Rp.5, 775,000

- Total LED Philips Philips 27 Watt

- 2 x Rp. $105,000=$ Rp. 210,000

\section{E. Comparison of Energy Used}

Each type of lamp has a different energy consumption. By adding up the total power consumption of each room will indicate the type of lamp that can save electrical energy.

Inayah Ujung Batu Elementary School Principal's Room Using Hannochs Lamp 8 Watt 440 Lumen

Energy usage for the use of the principal's room for 1 day is 12 hours wuth the total number of lamps are 6 pieces.

$$
\begin{aligned}
W & =P \times t \\
& =(8 W \times 30) \times 12 D \times 26 D=74,88 \mathrm{kWh}
\end{aligned}
$$

Using Philips LED Lights 33 Watt. Total Number of lamps 4 pieces,

$$
\begin{aligned}
W & =P \times t \\
& =(33 W \times 5) \times 12 D \times 26 D=51,48 \mathrm{kWh}
\end{aligned}
$$

Percentage of energy savings:

$$
\begin{aligned}
& =\frac{\text { Early }- \text { End }}{\text { Early }} \times 100 \% \\
& =\frac{74,88 \mathrm{kWh}-51,48 \mathrm{kWh}}{74,88 \mathrm{kWh}} \times 100 \%=31,25 \%
\end{aligned}
$$

Guest Room and Hall of Putri Tujuh Orphanage Dormitory

- Using Hannochs Lights 26 Watt and 45 Watt.

Energy consumption for a guest room and hall for 1 day is 12 hours with the total number of lamps 4 pieces Hannochs 26 Watt, and 15 pieces Hannochs 45 Watt. 


$$
\begin{aligned}
W & =P \times t \\
& =((8 W \times 30)+(45 W \times 15)) \times 12 H \times 30 D \\
& =329,4 \mathrm{kWh}
\end{aligned}
$$

- Using a Philips LED light 27 Watt and Philips LED 33 Watt.

The total number of lamps 2 pieces of Philips lamps 27 Watt and 9 pieces Philips 33 Watt.

$$
\begin{aligned}
W & =P \times t \\
& =((27 W \times 2)+(33 W \times 9)) \times 12 H \times 30 D \\
& =126,36 \mathrm{kWh}
\end{aligned}
$$

Percentage of energy savings:

$$
\begin{aligned}
& =\frac{\text { Early }- \text { End }}{\text { Early }} \times 100 \% \\
& =\frac{329,4 \mathrm{kWh}-126,36 \mathrm{kWh}}{329,4 \mathrm{kWh}} \times 100 \%=61,64 \%
\end{aligned}
$$

The room inside Fastabiqul Khairat Mosque

- Using Hannochs lamp 45 Watt

The use of energy for 1 day is 12 hours. Where the total number of lamps are 37 pieces

$$
\begin{aligned}
W & =P \times t \\
& =(45 W \times 37) \times 12 H \times 30 D=599,4 k W h
\end{aligned}
$$

- Using Philips 33 Watt Lamps

Total number of lamps is 19 pieces

$$
\begin{aligned}
W & =P \times t \\
& =(33 W \times 19) \times 12 H \times 30 D=225,72 \mathrm{kWh}
\end{aligned}
$$

Percentage of energy savings:

$$
\begin{aligned}
& =\frac{\text { Early }- \text { End }}{\text { Early }} \times 100 \% \\
& =\frac{599,4 \mathrm{kWh}-225,72 \mathrm{kWh}}{599,4 \mathrm{kWh}} \times 100 \%=62,3 \%
\end{aligned}
$$

The following is a comparison chart of the energy needed for each building at the Putri Tujuh Foundation.

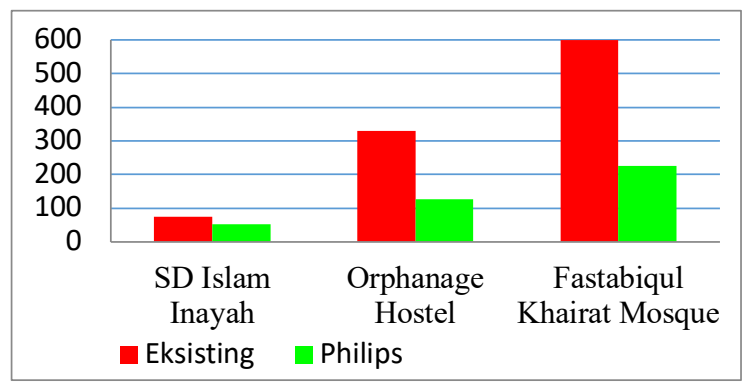

Figure 9: Energy comparison chart at Putri Tujuh Foundation building

\section{CONCLUSION}

Based on the evaluation of lighting quality that has been carried out at the Putri Tujuh Foundation, it can be concluded that:

a) The lighting system in the case study room has not reached the standards determined by SNI 61972011.

b) The evaluation results obtained the number of luminaries for the principal room of the Islamic Inayah Elementary School is 5 units of 33 Watt LED Philips lamps, the Guest Room of the Dormitory and the Hall of the Putri Tujuh Orphanage Dormitory each are 2 units Philips LED 27 Watts and 9 units Philips LED 33 Watts. Fastabiqul Khairat Mosque with 19 units of 33 watts LED Philips lamps.

c) The simulation using DIALux Evo 8.2 software shows the lighting strength of Inayah Islamic Elementary School's Principal Room is 376 lux, the Living Room and the Hall of the Putri Tujuh Orphanage Dormitory House are 165 Lux and 204 Lux, and the Fastabiqul Khairat Mosque Room is 214 Lux.

d) The comparison of energy used proves that the recommended lamp is more energy efficient than the lamp that is already installed. The Percentage of Energy Savings for Inayah Islamic Elementary School was $31.25 \%$. Guest Room and Dormitory Room of Putri Tujuh Orphanage 61.64\%. The Fastabiqul Khairat Mosque is $62.3 \%$.

The difference in the color of the wall affects the level of lighting power in the room. Color with a higher reflectance factor will increase the luminance strength and a lower reflectance factor will decrease the level of luminance.

\section{REFERENCES}

[1] Atmam \& Zulfahri, "Intensity analysis of information and electricity use in computer laboratory State Elementary School 150 Pekanbaru", Lancang Kuning University, 2015.

[2] Standardization 2011 SNI 6197-2004, "Measurement on workplace illumination", 2004.

[3] General Uniform Lighting Philips, Retrieved 29 July 2019.

[4] Havif, Ikhbal JH, "Quality evaluation of the lighting at the lecture hall building C Faculty of Engineering University of Riau", 2017.

[5] Irianto, C. G, "Optimization study of lecture room lighting system by utilizing natural light", Journal Volume 5 Number February 2, 2006 ISSN 1412-0372, Jakarta, Department of Electro-FTI Engineering Trisakti University, 2006.

[6] KEPMENKES RI, Nomor 1405 Tahun 2002, "Environmental health requirements of office and industrial work", Retrieved 8 December 2018.

[7] Satwiko, Prasasto, "Building physics", Yogyakarta, 2008.

[8] Suhardi, B, "Industrial work and Ergonomics System Design", Vol. 2 Directorate of VOCATIONAL Development, Jakarta, 2008.

[9] Wibiyanti, P.I, "Lighting study on small industry apparel and bag making in small industrial village milling", Thesis, Jakarta, 2008.

[10] Wisnu, Indarwanto, M, "Evaluation of natural and artificial lighting system in the working space of Paninggilan Utara village", Ciledug, Tangerang, 2017. 